\title{
Spending and Saving Behavior Towards the 2019 Indonesia Presidential Election
}

\author{
D Tamara, M P Lingga and D Rosmiaty \\ Executive in Strategic Management Program, Management Department, BINUS Business \\ School Master Program, Bina Nusantara University, Jakarta, Indonesia \\ dtamara@binus.edu
}

\begin{abstract}
This paper investigates the spending and saving behavior towards the next presidential election. Specifically, this paper discusses about spending and saving behavior of Gen $\mathrm{Y}$ in Indoensia. The research adopted a quantitative approach through a survey method with sample of Gen Y in Jakarta. This study reveals that the Presidential Election is an important political event and they are optimistic about the process and results of the 2019 Presidential Election based on 2014 Presidential Election. However, the next presidential election is not significantly impact spending and saving behavior of the Gen Y. The reason is because the price of goods are still reasonable. Prices and promotions are the dominant factors for making decisions on purchases. They will save more because they think saving is very important, especially to manage unexpected potential risks.
\end{abstract}

Keywords: Spending, saving behavior, presidential election, Indonesia

\section{INTRODUCTION}

The Indonesian population reached 254.9 million in 2015 , with more than $33 \%$ being the young population from 15-34 years old. In urban areas such as Jakarta, the young population can comprise more than $40 \%$. This young population will be further known as Generation Y. According to the Indonesian Central Bureau of Statistics (BPS), 50\% of Indonesia's productive age population today comes from Gen Y, and they are the generation that will play an important role in Indonesia for the next 10-20 years.

Talking about potential market, the predicted population of the middle-class and affluent customers (MAC) in Indonesia by 2020 will have reached 141 million, or approximately 64 percent of its current population, based on the Boston Consulting Group. Similar to this study, the urban middle-class Gen Y will reach 35 million people or $13 \%$ of Indonesia's population in 2020[1]. From a marketing perspective, such a number will surely become a big potential market.

Indonesia is the fourth most populous country and the third largest democracy in the world. The Presidential Election is the biggest democratic event that is held every 5 years and the next election will be in April 2019. Democracy, politics, and economics are often intertwined, with the winners of an election having influence over policies that can affect the lives of millions. In this case, Gen Y has become an increasingly important subject of study due to the size of the population and their buying power.

The main purpose of this study is to analyze what the spending and saving expectations from Gen Y in Jakarta toward Indonesia's Presidential Election in 2019. The results of the study are expected to help various stakeholders, especially the marketers, retailers, and bankers, make decision towards the spending and saving behavior. 


\subsection{Spending behavior}

Consumption expenditure is spending on goods and services to satisfy needs and wants, including anything from spending on refrigerators to medical services to movie tickets to food. The final consumption expenditure is classified in terms of durable goods, semi-durable goods, non-durable goods, and service [1]. Durable goods are tangible goods that tend to last for more than a year. Tangible goods are things that can be touched, i.e. physical goods. Examples of durable goods are furniture, household appliances, cars, and personal computers. These goods are all things that we use over and over for several years and that we do not dispose of very quickly. Semi-durable goods are tangible goods with a shorter lifecycle than durable goods. They are also not as expensive as durable goods. Examples of semi-durable goods are clothing and footwear, motor vehicle tires, parts and accessories, and glassware. Non-durable goods are tangible goods that are used once only. Common examples are food and gasoline. Services include consumption expenditures for activities that provide direct satisfaction of needs and wants, without the production of tangible goods. Common examples are rent, medical services, information, entertainment, and education.

According to Deloitte [2], Indonesian consumer is very sensitive to price. They desire promotions and do price comparisons. With more access to information, they will hunt for value-for-money propositions. Indonesian consumers strongly prefer local brands but at the same time, they are beginning to place greater emphasis on other product attributes such as health and overall quality. Across all product categories, price and specific category drivers remain the top two attributes influencing purchasing decisions. Moreover, Indonesian are known as a strong consumerism. Higher income and credit growth was translated to improve living standards beyond home and car ownership. This creates stronger consumer demand, especially for such lifestyle products as personal electronics, clothes, watches, domestic appliances and fashion, and also entertainment and dining out [3][4].

\subsection{Saving Behavior}

Saving activity is how much you put into saving account after all expenditures are counted from the disposable income in monthly basis. Saving money can help a person become financially secure and provide a safety net in case of an emergency. The importance of saving money is basically because we cannot predict the future. Saving money can help you become financially secure and provide a safety net in case of an emergency.

Fisher and Anong [5] identify three types of saving habit such as 1) contractual savings, where one put installments on fixed assets such as mortgage, housing or apartment, retirement or insurance. Second is discretionary saving, where one deliberately saves. This includes save for Emergency Funds, save for vacations and other luxury items, and save for a new car [6]. Saving for emergency funds means to set aside funds to cover unexpected expenses. The unexpected expenses can be car repair, medical issue or even a sudden job loss. Saving for retirement is to save money when you are retired or decided not to work anymore. Saving for down payment housing is important because the local culture still appreciates one with his own home, not rented. Bigger down payment, means lower installment.

Third savings is residual savings, where one left some money by default. This includes saving for sinking funds is the money you set aside for future repairs or improvements on your car, home, or other possessions. Saving for education is to save money for future education, either for master or doctorate. Saving for children education is also part of this. 
This categorization is based on [7], that study behavioral or psychological approach to saving behavior. He compared two saver groups to differentiate the behavior between discretionary and residual saving. Indonesian banking funding/ saving products in a conventional bank and Syariah bank are as follows: Time Deposit, Checking Account, Savings

\subsection{Gen $Y$}

Who is the Millennial Generation? After World War II, a demographic group (cohort) was divided into four generations, namely the Baby Boomer generation, Generation X, Generation $\mathrm{Y}$, and Generation $\mathrm{Z}$. The Baby Boomer generation is the generation who was born after the Second World War (currently aged 53 up to 70 years). They are known as the Baby Boomer generation since the birth rate was very high in that era. Gen $\mathrm{X}$ is the generation that was born from 1965 to 1980 (currently aged 37 to 52 years). Gen Y is the generation born between 1981 and 2000 , or is currently aged 17 years to 36 years. Gen Y is the demographic group after Gen $\mathrm{X}$, while Gen $\mathrm{Z}$ is the generation that was born after 2000 to the present.

Gen $\mathrm{Y}$ in 2020 will be in the age range of 20 to 40 years, and they are expected to make up $70 \%$ of the total productive age population. This is a childbearing age range that will be the backbone of the Indonesian economy. According to data from the Central Statistics Agency (BPS), Indonesia's population aged 20 to 40 years old in 2020 allegedly amounted to 83 million people or $34 \%$ of the total population of Indonesia that reached 271 million.

Gen $\mathrm{Y}$ is unique and different from the other generations. It is heavily influenced by the rise of smartphones, the spread of the Internet, and the rise of social networking media (social media). Those three influenced mindsets, values, and behaviors are adopted. Gen Y is "technology savvy". What is striking from Gen Y rather than the previous generation is about the use of technology and pop culture/ music. The lives of Gen Y cannot be separated from technology, especially the Internet. Entertainment/ amusement has become a staple for this generation [8].

The urban middle-class Gen $\mathrm{Y}$ is a generation with unique characteristics. The characteristics of this generation are reflected in the 3Cs: creative, confident, and connected. First, the urban middle-class Gen Y is a creative generation. They are accustomed to thinking outside of the box, being rich in ideas and thoughts. Second, they are a highly confident generation. These young people dare to express their opinions without hesitation. Third, they are also a connected generation. They are good at socializing, especially within the communities they follow. Besides that, they are also active in using the Internet and social media. These characteristics of Gen Y are mainly influenced by rapid technological advancements, especially for gadgets and the Internet.

Indonesia is the most populous country in ASEAN with a population of some 260 million strong. It is also the world's fourth-largest consumer market in terms of population size, trailing behind only China, India, and the USA. Its average of a $6 \%$ per annum economic growth between 2007 and 2016 - the strongest performance among all ASEAN-5 countries - has created a reasonably solid foundation for the increased breadth and depth of demand for products and services among the middle class, a demographic that has become an increasingly dominant force within its consumer market [4]. The Customer Insights survey from Deloitte in year 2016, pointed out that the profile of the Indonesian consumer has been steadily evolving along two key dimensions: the increase in disposable household incomes and the rise in urbanization rates. Over the last decade, Indonesia has experienced a steady growth in trajectory in terms of GDP, and this has ultimately led to an increase in household disposable incomes. Coupled with growth in its population size, this trend has given rise to a significant middle class with headroom to increase discretionary spending. The Alvara Research Center [8] tried to 
predict the number of urban middle-class Gen Y population using secondary data from BPS and BCG. As previously mentioned, the urban population in Indonesia in 2020 based on the Predictive BPS is $56.7 \%$ or 154 million people, the middle class population is 141 million inhabitants, and Gen Y is comprised of a population of 86 million. The theory of comparison used to obtain the predicted number of urban middle-class Gen Y, assuming the ratio of the number of urban: rural residents is 56.7: 43.3, (referring BPS) the comparison of the middle class: non-middle class is 52:48 (referring to BCG), the comparison of the Gen Y: non-Gen Y is 35: 65 (referring to BPS), and the comparison of the middle class urban: rural middle class is 70:30 (referring to ADB). Within the comparison theory, it can acquire the projections of the urban middle class Gen Y population in 2020 at 35 million people or $13 \%$ of Indonesia's population in 2020 which is projected at 271 million.

The 35 million people of middle-class Gen Y in 2020 represents $18.39 \%$ of the registered voters in the Presidential Election in 2014 where $70 \%$ or 25 million out of 35 million live in an urban area. Indonesia's GDP per capita in 2016 was USD 3,570.3 or equivalent to Rp47,514,651 (World Bank Report 2016). The 35 million people contributing to USD 124.9 billion of the Indonesian GDP or $13.4 \%$ out of USD 932.3 billion of the total Indonesian GDP 2016. The average expenditure of the middle class Gen Y is Rp70 trillion to Rp105 trillion (Nielsen Report 2017) or an average of $0.85 \%$ of the Indonesia Gross National Expenditure 2016 amounting to Rp12,310.6 trillion. With $18.39 \%$ of young voters, $13.4 \%$ of the Indonesian GDP, and $0.85 \%$ of the Indonesia Gross National Expenditure, it surely will affect the Presidential Election in 2019.

The definition of the middle class, according to Asia Development Bank (ADB), is considered most suitable to be applied for Asian countries. ADB defined the middle class based on expenditure per capita per day which is between $\$ 2-\$ 20$ and is divided into 3 groups as below:

1) Lower middle class: expenditure $\$ 2-\$ 4$

2) Middle middle class: expenditure $\$ 4-\$ 10$

3) Upper middle class: expenditure $\$ 11-\$ 20$

The group of urban middle-class Gen $\mathrm{Y}$ is a group of creative and confident people. According to Visa (2012), this generation also has the characteristic of being ambitious related to achievements and ideals. The characteristics cause repercussions in the world of work and entrepreneurship. In a period of economic stages, the future economic stage is the period of the creative economy. So the role of the urban middle-class Gen Y cannot be ignored. They will be the trigger for the future of Indonesia's creative economy. Knowingly or not, another trend of Gen $\mathrm{Y}$ is the more comfortable working environment will accommodate freedom of expression and work.

According to Oxford's Advanced Learning Dictionary, an election is the process of choosing a person or a group of people for a position, especially a political position, by voting. In Indonesia, Presidential Elections are held every five years. The voting age is 17 . However, married persons regardless of age can vote. Around 185 million of Indonesia's 250 million people are eligible voters. Voting is weighed in favor of the less populous peripheral islands. Indonesia has held four sets of democratic national elections, in 1999, 2004, 2009, and 2014. Currently in Indonesia, there is very limited research on the impact of Presidential Elections, especially on Generation $\mathrm{Y}$ and the impact on their spending and saving behavior.

\section{METHOD}

There are various methods of selecting the samples and they are categorized as probability and non-probability sampling [9]. For this research study the targeted population was middle 
class Generation Y in Jakarta. All the respondents were within the age range of 17-36 years old to represent Gen Y, with daily spending of 2-20 USD to represent the middle class.

Convenience sampling was used in this study by collecting information from members of the population who were conveniently available to provide it. The respondents were people who currently lived in Jakarta and fit the criteria of the middle class Generation Y group. The questionnaire was distributed through an online survey and the details are explained in the questionnaire distribution section.

Data for the literature review was mostly gathered from secondary data. It comprised journals, online business magazines, online newspapers, and archived materials. According to data from Biro Pusat Statistik (2015), the population in DKI Jakarta was 10,177,924 people. As there are approximately $40 \%$ of Gen Y in Jakarta's population, for this study around 100 sets of questionnaires were distributed.

According to Sekaran [9], a questionnaire is a written set of questions to which respondents record their answers. For this research study, a set of questions was designed according to the needs of this study. The entire questionnaire was comprised of closed-ended questions where the respondents had to select from pre-assigned answers. The questionnaire was designed using Indonesian language.

The questionnaire was divided into four sections. The first section concerned the characteristics of the respondents where the demographic profile such as age, gender, education, marital status, city of domicile, how many people are dependent on the respondent, residential status, transportation ownership and usage, insurance ownership, daily spending, monthly spending, current profession, how long the respondent has been working in the current profession, position/ job title, and status of employment were captured. The second section was related to Presidential Elections with the respondents' participation in the Presidential Elections of 2014 and 2019, and their feedback on the smoothness and safety of the Presidential Elections. The third section was concerned with the spending behavior and captured the source of information, channel of spending, and spending decisions with the upcoming Presidential Election in 2019. The fourth section was on the saving behavior where the percentage, instrument, purpose, and changes of behavior in saving and investment in relation to the Presidential Election were captured.

\section{RESULT AND DISCUSSION}

A total of 111 sets of questionnaires were collected from an online survey form of Jakarta city residents. Figure 1 below shows the year of birth of the respondents, which was from 19812000 and fell into the Generation Y classification. The majority of the respondents were born in 1991-2000 who comprised $61 \%$.

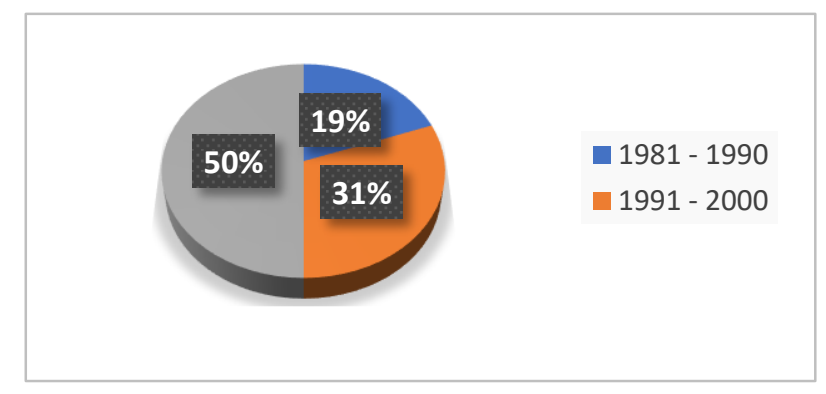

Figure 1. Respondents Birth Profiles. 
Figure 2 below shows the gender of the respondents, who are composed of $50 \%$ females and $50 \%$ males.

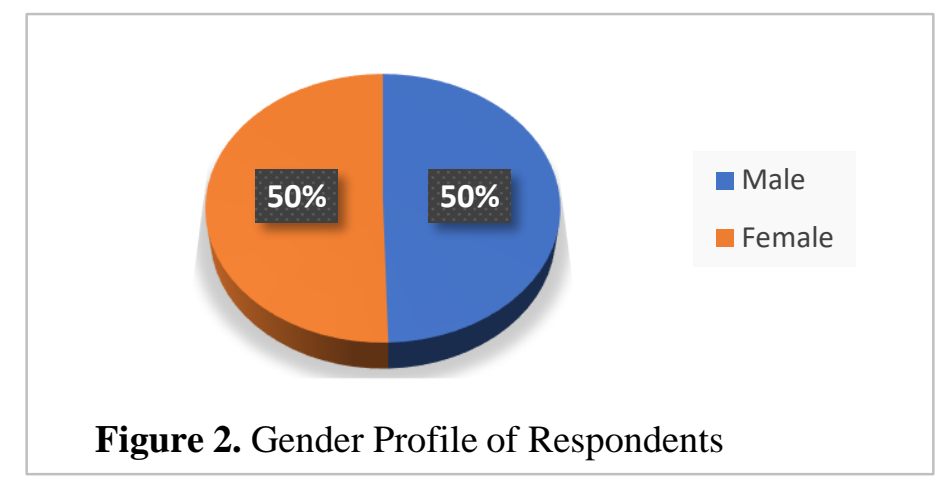

Figure 2. Gender Profile of Respondents

Figure 3 below shows the educational background of the respondents, which is comprised of $10 \%$ high school graduates, $78 \%$ undergraduate degree holders, and $12 \%$ post-graduate degree holders.

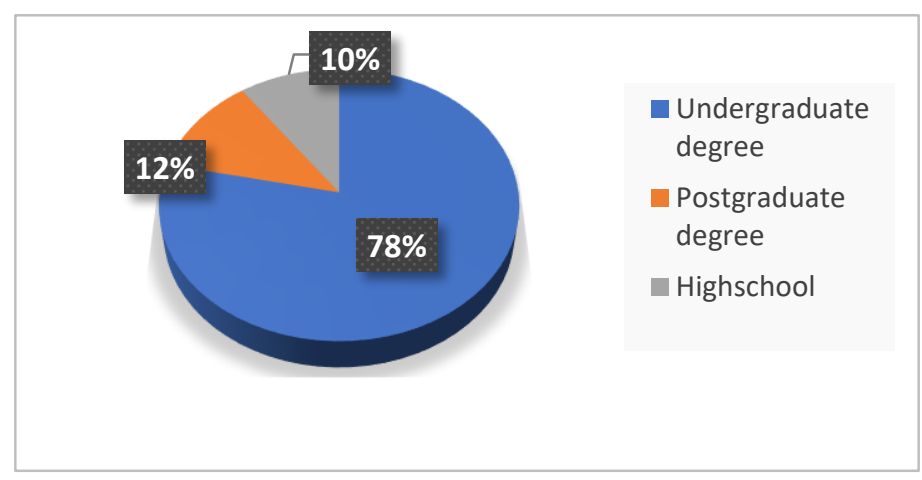

Figure 3. Educational Background.

Figure 4 below shows the marital status of the respondents, which is comprised of $34 \%$ single and $66 \%$ married.

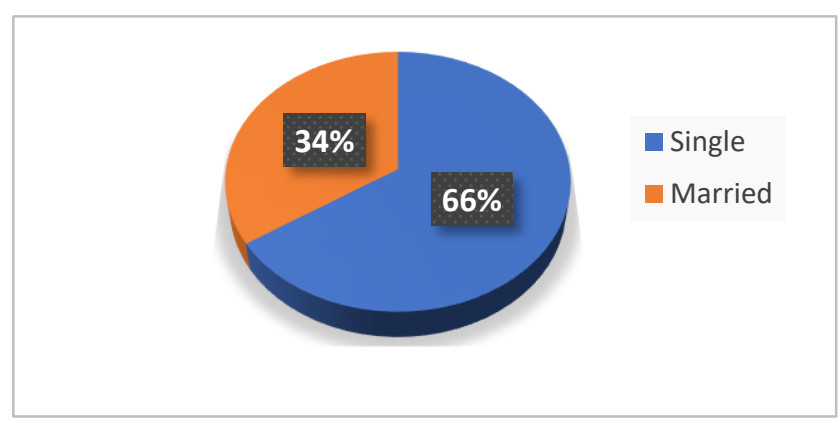

Figure 4. Marital Status of the Respondents. 
Figure 5 below shows the municipality residential areas of the respondents, which are comprised of 5\% Central Jakarta, 7\% East Jakarta, 9\% West Jakarta, 27\% East Jakarta, and 52\% South Jakarta.

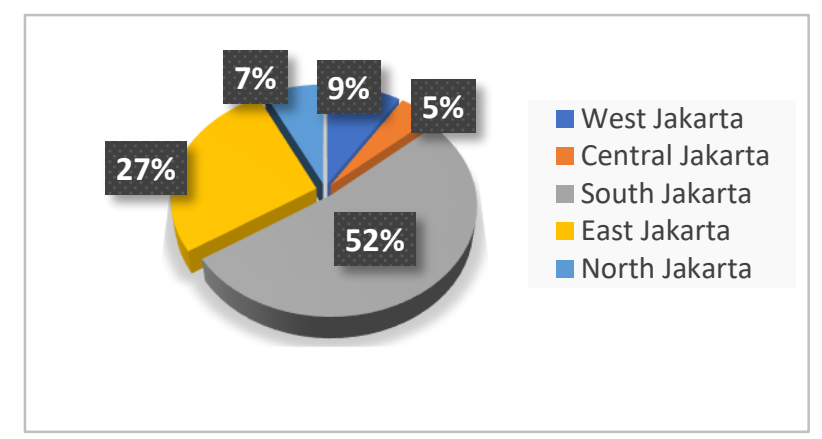

Figure 5. Municipality of the Respondents.

Figure 6 below shows the number of people supported by the respondents, which is comprised of $4 \%$ for more than 3 people, $7 \%$ for 3 people, $24 \%$ for 2 people, $11 \%$ for 1 person, and $54 \%$ for zero people.

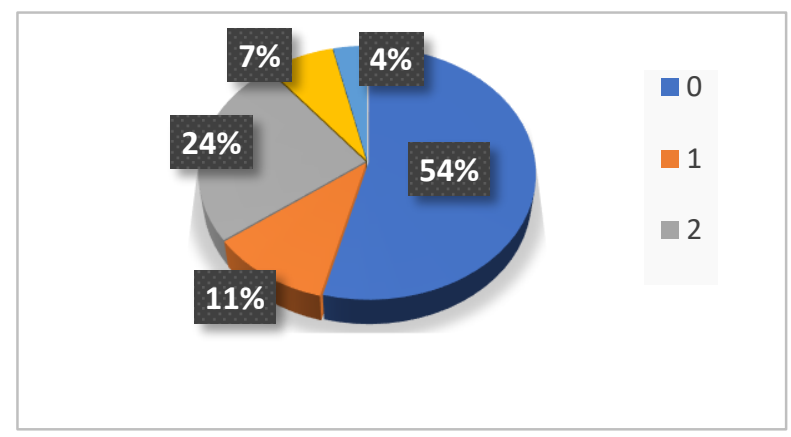

Figure 6. Number of People Supported by the Respondents.

Figure 7 below shows the residential status of the respondents, which is comprised of $19 \%$ with personal owned residence, $31 \%$ with rented residence, and $50 \%$ still staying with parents.

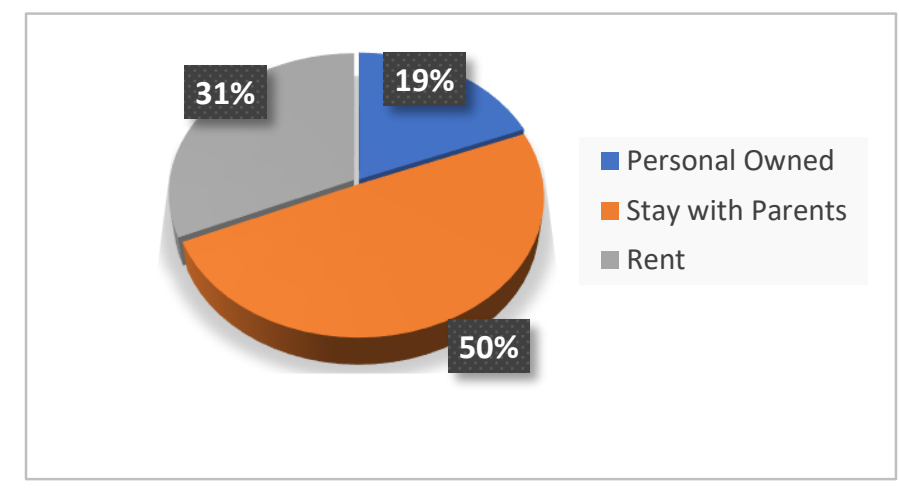


Figure 7. Residential Status of the Respondents.

Figure 8 below shows the vehicle ownership of the respondents, which is comprised of $17 \%$ with car ownership, 53\% with motorcycle ownership, and 30\% having both a car and motorcycle.

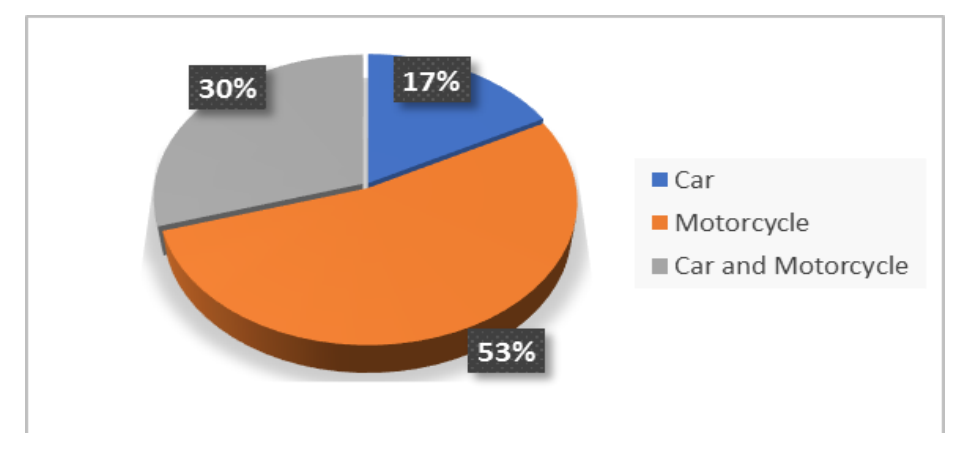

Figure 8. Vehicle Ownership of the Respondents.

Figure 9 below shows the private insurance ownership of the respondents, which is comprised of $28 \%$ with no ownership and $72 \%$ with ownership.

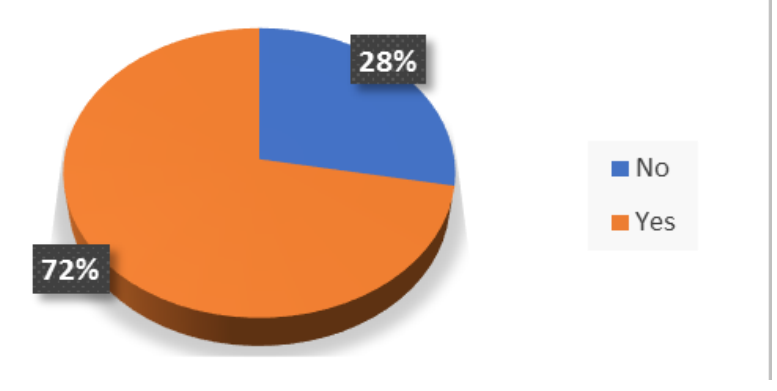

Figure 9. Private Insurance Ownership of the Respondents.

Figure 10 below shows the average personal daily spending of the respondents, which is comprised of $42 \%$ with spending USD 2-4, $41 \%$ with spending USD 4-10, $14 \%$ with spending USD 14-20, and 3\% with spending above USD 20.

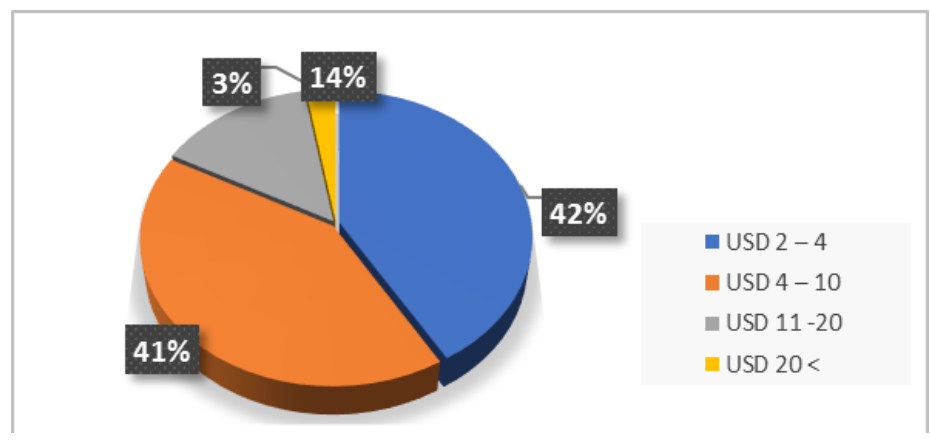

Figure 10. Average Personal Daily Spending of the Respondents. 
Figure 11 below shows the average monthly spending of the respondents, which is comprised of $60 \%$ with spending below Rp 4 million, 22\% with spending Rp 4-6 million, $10 \%$ with spending Rp 6-10 million, 5\% with spending Rp 10-20 million, and 3\% with spending above Rp 20 million.

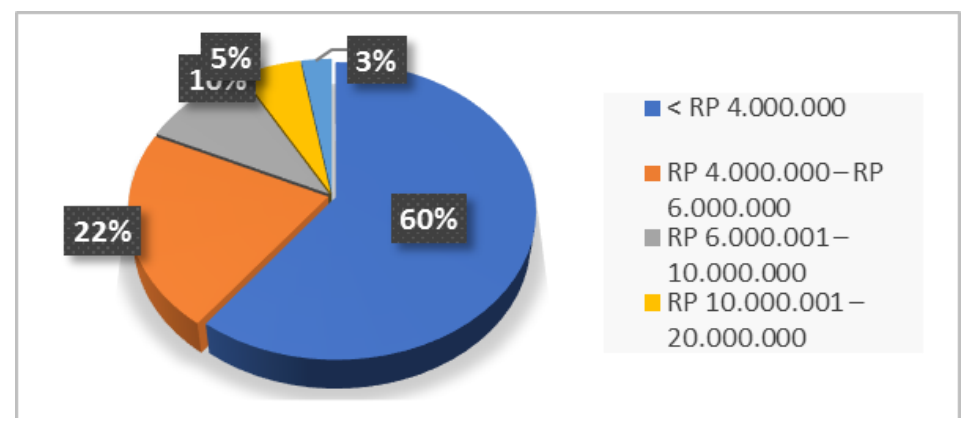

Figure 11. Average Monthly Spending.

Figure 12 below shows the working status of the respondents, which is comprised of $1 \%$ as students, $3 \%$ in the government sector, $11 \%$ as entrepreneurs, and $85 \%$ in the private sector.

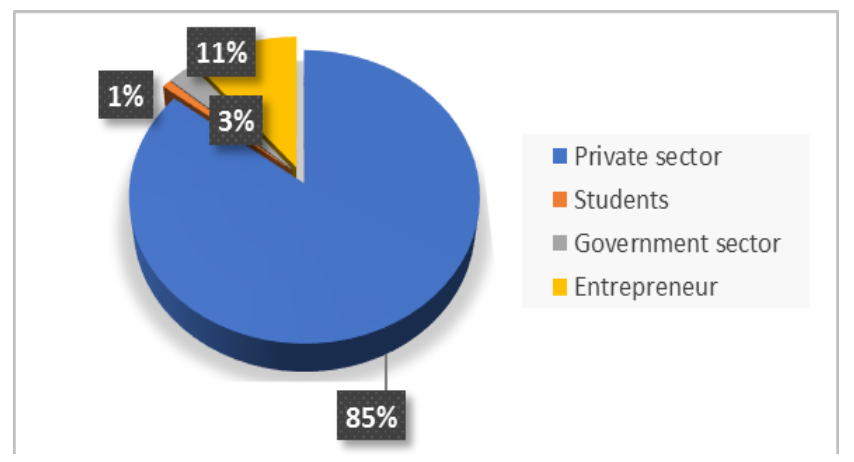

Figure 12. Working Status of the Respondents.

Figure 13 shows the working years of the respondents, which is comprised of $1 \%$ as students, $1 \%$ unemployed, $13 \%$ worked above 8 years, $26 \%$ worked between $4-8$ years, and $59 \%$ worked between 1-3 years.

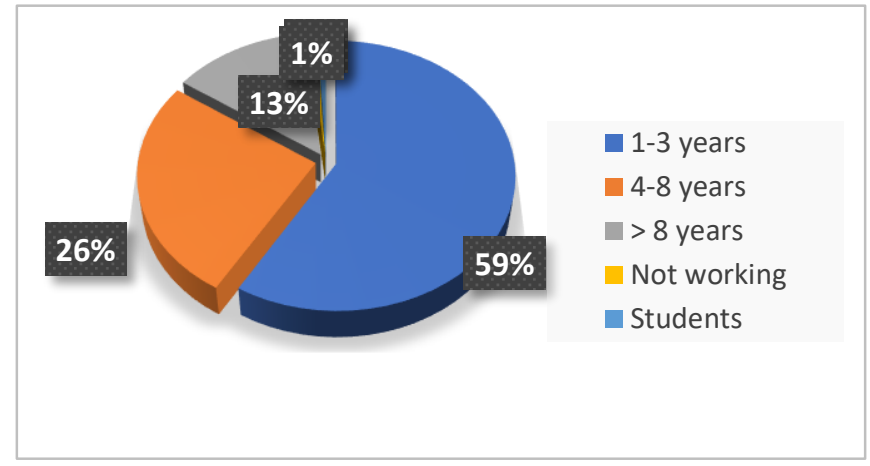


Figure 13. Working Years.

Figure 14 below shows the job titles of the respondents, which are comprised of $1 \%$ unemployed, $2 \%$ as students, $3 \%$ as executives, $3 \%$ as entrepreneurs, $5 \%$ as supervisors, $17 \%$ as managers, and $69 \%$ as staff.

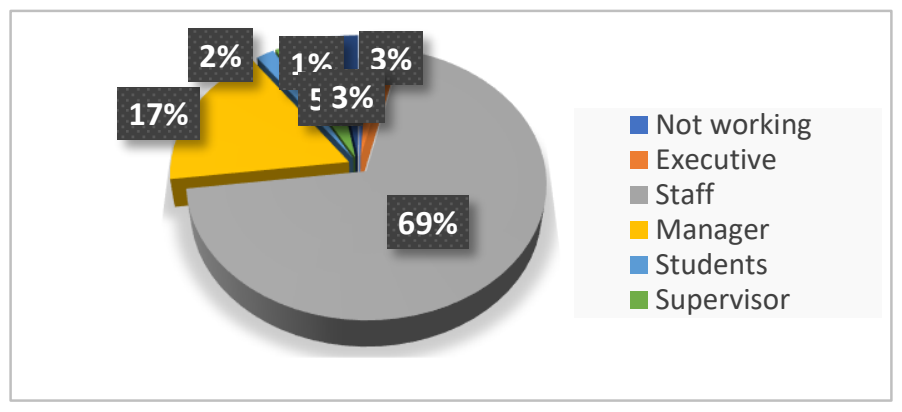

Figure14. Job Titles.

Figure 15 shows the work employment status of the respondents, which is comprised of $1 \%$ unemployed, $1 \%$ as students, $2 \%$ as entrepreneurs, $4 \%$ as outsourcing, $45 \%$ as contract, and $47 \%$ as permanent.

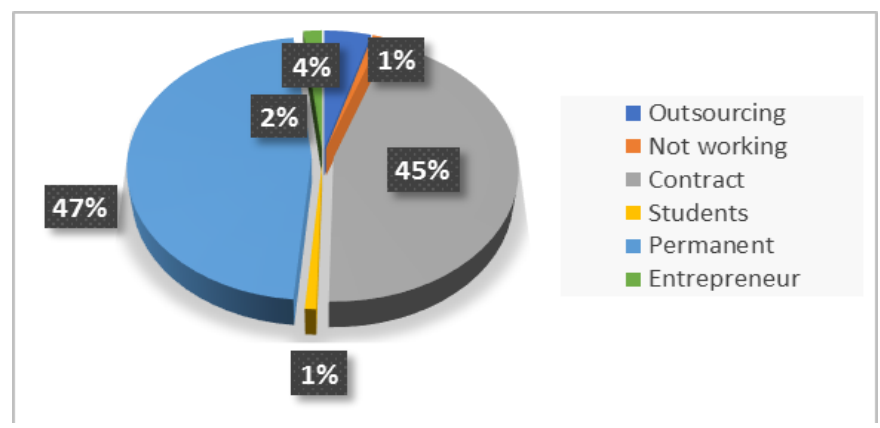

Figure 15. Work Employment Status of the Respondents.

Figure 16 details the respondents' participation in the 2014 Presidential Election, which is comprised of $11 \%$ did not participate and $89 \%$ participated. 


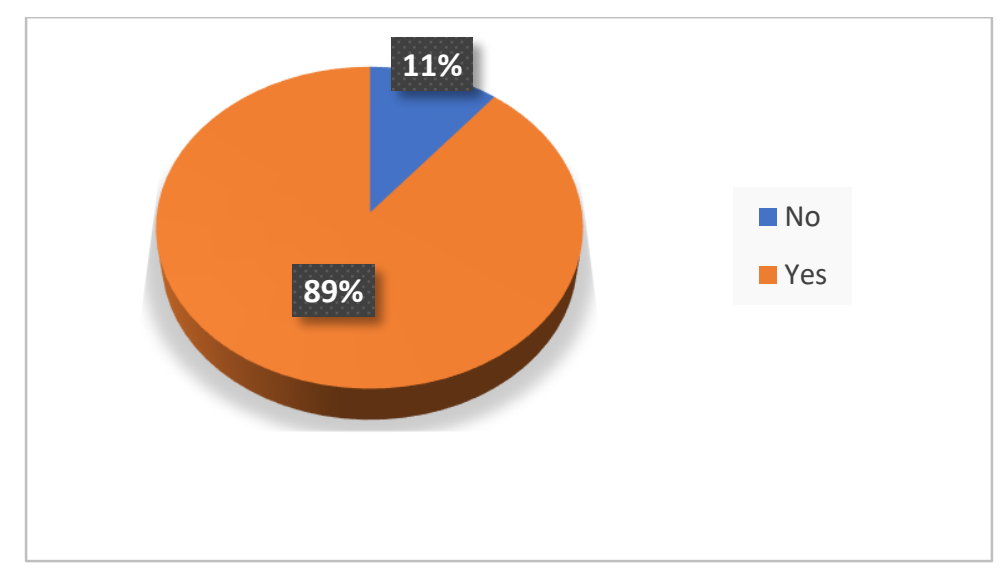

Figure 16. Respondents' Participation in the 2014 Presidential Election.

Figure 17 shows the respondents' expected participation in the upcoming 2019 Presidential Election, which is comprised of 3\% will not participate, 5\% do not know yet, and $92 \%$ will participate.

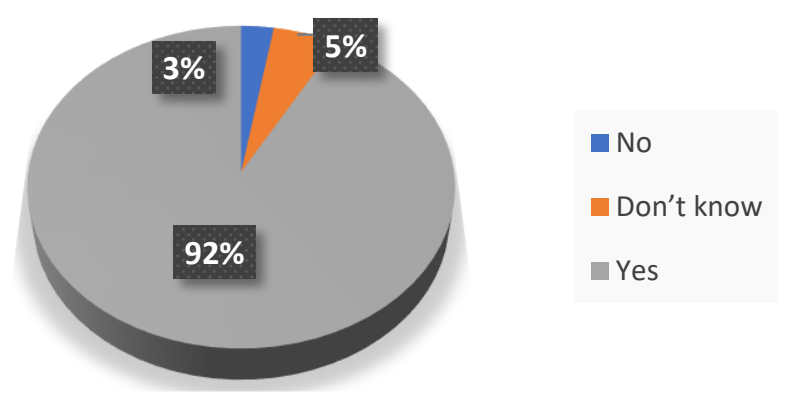

Figure 17. Respondents' Participation in the Upcoming 2019 Presidential Election

Figure 17. Respondents' Participation in the Upcoming 2019 Presidential Election.

The results in Table 2 below shows that $89.2 \%$ of the respondents think the execution of the Presidential Election in 2014 was smooth (with a mean of 3.5 from a scale of 1-5), as $87.4 \%$ of the respondents think the execution of the Presidential Election in 2014 was safe (with a mean of 3.4 from a scale of 1-5), and 78.4\% of the respondents think the execution of the Presidential Election in 2014 had a good outcome (with a mean of 3.4 from a scale of 1-5). 
Table 1. Cronbach Alpha Testing.

\begin{tabular}{|c|c|c|c|}
\hline \multicolumn{4}{|c|}{ Reliability Statistics } \\
\hline \multicolumn{2}{|c|}{ Cronbach's Alpha } & \multicolumn{2}{|r|}{$\mathrm{N}$ of Items } \\
\hline \multicolumn{2}{|r|}{.757} & \multicolumn{2}{|r|}{17} \\
\hline \multicolumn{4}{|c|}{ Case Processing Summary } \\
\hline & & $\mathrm{N}$ & $\%$ \\
\hline \multirow[t]{3}{*}{ Cases } & Valid & 111 & 97.4 \\
\hline & Excluded $^{\mathrm{a}}$ & 3 & 2.6 \\
\hline & Total & 114 & 100.0 \\
\hline
\end{tabular}

Table 2. Responses to the 2014 Presidential Election.

\begin{tabular}{ccccc}
\hline $\begin{array}{c}\text { Question } \\
\text { No. }\end{array}$ & Variables & $\begin{array}{c}\text { Likert Scale } \\
\mathbf{1 - 2}\end{array}$ & $\begin{array}{c}\text { Likert } \\
\text { Scale 3-5 }\end{array}$ & Mean \\
\hline $\mathbf{2 0}$ & Execution smoothness in 2014 & $10.8 \%$ & $89.2 \%$ & 3.5 \\
\hline $\mathbf{2 2}$ & Safe execution in 2014 & $12.6 \%$ & $87.4 \%$ & 3.4 \\
\hline $\mathbf{2 4}$ & Good outcome in 2014 & $21.6 \%$ & $78.4 \%$ & 3.4 \\
\hline
\end{tabular}

The results in Table 3 below reveal that $99.1 \%$ of the respondents think that the Presidential Election is a very important political event (with a mean of 4.3 from a scale of 1-5), $99.1 \%$ of the respondents think that the Presidential Election will impact all aspects (with a mean of 4.2 from a scale of 1-5), 90.1\% of the respondents think that the Presidential Election in 2019 will run smoothly (with a mean of 3.6 from a scale of 1-5), $86.5 \%$ of the respondents think that the Presidential Election in 2019 will run safely (with a mean of 3.4 from a scale of 1-5), $92.8 \%$ of the respondents think that the Presidential Election in 2019 will have a good outcome (with a mean of 3.5 from a scale of 1-5), 58.6\% of the respondents think that the Presidential Election in 2019 will impact the supply of goods and price increases (with a mean of 2.8 from a scale of $1-5), 71.2 \%$ of the respondents admitted to making impulsive buying decisions (with a mean of 3.3 from a scale of 1-5), $97.3 \%$ of the respondents agreed about the importance of prices and promotions (with a mean of 4.1 from a scale of $1-5$ ), $54.1 \%$ of the respondents think that the Presidential Election in 2019 will not impact their spending behavior (with a mean of 2.7 from a scale of 1-5), 55\% of the respondents think that the Presidential Election in 2019 will not 
impact the increase of their commodity item buffer stock (with a mean of 2.6 from a scale of 15), $57.7 \%$ of the respondents think that the Presidential Election in 2019 will impact the decrease of lifestyle spending (with a mean of 3 from a scale of 1-5), 99.1\% of the respondents agreed about the importance of saving (with a mean of 4.5 from a scale of 1-5), $61.3 \%$ of the respondents will increase their saving if there is a risk of safety (with a mean of 4.1 from a scale of $1-5)$, and $71.2 \%$ of the respondents think that the Presidential Election will not impact their saving behavior (with a mean of 2.8 from a scale of $1-5$ ).

Table 3. Response towards the 2019 Presidential Election.

\begin{tabular}{|c|c|c|c|c|}
\hline $\begin{array}{l}\text { Question } \\
\text { No. }\end{array}$ & Variables & $\begin{array}{c}\text { Likert Scale } \\
1-2\end{array}$ & $\begin{array}{c}\text { Likert Scale } \\
3-5\end{array}$ & Mean \\
\hline 18 & Importance of the Presidential Election & $0.9 \%$ & $99.1 \%$ & 4.3 \\
\hline 19 & Impact of the Presidential Election & $0.9 \%$ & $99.1 \%$ & 4.2 \\
\hline 21 & Execution smoothness in 2019 & $9.9 \%$ & $90.1 \%$ & 3.6 \\
\hline 23 & Safe execution in 2019 & $13.5 \%$ & $86.5 \%$ & 3.4 \\
\hline 25 & Good outcome in 2019 & $7.2 \%$ & $92.8 \%$ & 3.5 \\
\hline 26 & $\begin{array}{l}\text { Impact in the supply of goods and price } \\
\text { increases }\end{array}$ & $41.4 \%$ & $58.6 \%$ & 2.8 \\
\hline 29 & Impulsive buying decision & $28.8 \%$ & $71.2 \%$ & 3.3 \\
\hline 30 & Importance of prices and promotions & $2.7 \%$ & $97.3 \%$ & 4.1 \\
\hline 31 & Impact on spending behavior & $54.1 \%$ & $45.9 \%$ & 2.7 \\
\hline 32 & Increase of basic commodity items & $55.0 \%$ & $45.0 \%$ & 2.6 \\
\hline 33 & Decrease in lifestyle spending & $42.3 \%$ & $57.7 \%$ & 3.0 \\
\hline 38 & Importance of saving & $0.9 \%$ & $99.1 \%$ & 4.5 \\
\hline 39 & Saving increment due to risk condition & $38.7 \%$ & $61.3 \%$ & 4.1 \\
\hline 40 & Impact on saving behavior & $71.2 \%$ & $28.8 \%$ & 2.8 \\
\hline
\end{tabular}

\section{CONCLUSION}

From the questionnaire results, it can be seen that the majority of the respondents think the Presidential Election was conducted smoothly, safely, and with a good outcome in 2014. Thus, it impacted their view on the upcoming Presidential Election in 2019, as they expect it will be as smooth, safe, and with a good outcome as in 2014. In turn, even though the majority of the respondents think it will impact the supply of goods and price increases, they will not increase buying basic commodity items but will restrain themselves from lifestyle spending. Also, even though the majority of the respondents think the Presidential Election will not impact their saving behavior, they will increase the saving level if there is any risk in safety. Most 
respondents are more concerned with the prices and promotions for making purchase decisions. Therefore, producers and suppliers need to pay more attention to the prices and promotions when they offer products or services to Gen Y in Jakarta.

\section{REFERENCES}

[1] M. Aguiar and E. Hurst, “Consumption versus Expenditure,” J. Polit. Econ., vol. 113, no. 5, pp. 919-948, Oct. 2005.

[2] Deloitte, "Deloitte Consumer Insights: The evolution of Indonesian consumer," Deloitte, 2016.

[3] B. Suryanta, “An Evaluation of Indonesian Capital Market Co-integration with ASEAN 4 to Enter the ASEAN Capital Market Integration in Accordance to ASEAN Economic Community (AEC) 2020 Scheme: Should Indonesia Enter or Postpone?," Indones. Cap. Mark. Rev., vol. 3, no. 1, Aug. 2014.

[4] H. Research, "ASEAN in Focus: The Indonesian Consumer Market," Hongkong Means Business. [Online]. Available: https://hkmb.hktdc.com/en/1X0A91HG/hktdcresearch/ASEAN-in-Focus-The-Indonesian-Consumer-Market. [Accessed: 16-Dec2018].

[5] P. Fisher and S. Anong, "Relationship of Saving Motives to Saving Habits," J. Financ. Couns. Plan., vol. 23, no. 1, pp. 63-79, 2012.

[6] C. Miriam, "Top 7 Reasons to Save Your Money," The Balance. [Online]. Available: https://www.thebalance.com/learn-the-most-important-reasons-to-save-money2386123. [Accessed: 14-Dec-2018].

[7] G. Katona, Psychological economics, Elsevier Scientific. New York: Publishing Company, 1975.

[8] H. Ali and L. Purwandi, Indonesia 2020: The Urban Middle Class Millennials. Jakarta: PT Alvara Strategi Indonesia, 2016.

[9] U. Sekaran and R. Bougie, Research methods for business. UK: John Wiley and Sons, 2016. 